\title{
Toxicity and color reduction of reactive dyestuff RB 21 and surfactant submitted to electron beam irradiation
}

\author{
Melo ${ }^{1}$ C.G., Rosa ${ }^{1,2}$ J.M., Garcia ${ }^{1}$ V.S.G., Borrely ${ }^{1}$ S.I., Pereira ${ }^{1}$ M.C.C. \\ ${ }^{1}$ Instituto de Pesquisas Energéticas e Nucleares (IPEN / CNEN - SP) \\ 05508-000, Av. Professor Lineu Prestes, 2242, São Paulo, SP, Brazil \\ camila.gomes.melo@hotmail.com \\ ${ }^{2}$ Faculdade de Tecnologia SENAI Antoine Skaf \\ 03008-020, Rua Correia de Andrade, 232, São Paulo, SP, Brazil
}

jotarosa@hotmail.com

\begin{abstract}
There is an unwelcome reaction between the coloring and the water during the dyeing procedure, a portion of the coloring agent is lost in the bathing and it will compose the final whole effluent. The high absorbance index is related to lost dyestuffs and they also contribute with the toxic effects to the aquatic biota. In addition, these effluents contain large quantity of surfactants applied during dyeing baths, which also contribute to the high toxicity in these samples. The objective of this study was to evaluate electron beam irradiation technology, applied in samples of the Color Index Reactive Blue 21 (RB 21) dyestuff and in samples of surfactant non-ionic and in order to reduce toxicity for both and for RB 21, color reduction. Among the objectives of the study there are the dyestuff exhaustion degree, and some physical-chemical parameters. The acute toxicity assays were carried with Daphnia similis microcrustacean and the results of the dyestuff solution were: the irradiated samples with concentration $0.61 \mathrm{~g} \mathrm{~L}^{-1}$ did not present significant results, the EC $50(\%)$ value was to 58.26 for irradiated sample with $2.5 \mathrm{kGy}$ and EC 50 (\%) 63.59 for sample irradiated with $5 \mathrm{kGy}$. The surfactant was more toxic than RB 21, with EC 50 (\%) value at 0.42 . The color reduction reached $63.30 \%$ for the sample of the lowest concentration of effluent. There was a reduction of $\mathrm{pH}$ during irradiation.
\end{abstract}

Keywords: electron beam irradiation, toxicity, color reduction, reactive dyestuff, surfactant. 


\section{INTRODUCTION}

The water is a vital resource for the human consumption, for keeping health biota (fauna and flora), and also agricultural and industrial suitable production. However, water is becoming more and more scarcer even after hundreds of regulations. There is a huge need for rational use of water, avoiding the wastes and the pollution, which is related not only environmentalists, but also governmental institutions and its productive processes. There are many people (1/6 of world population) that has no access to clean water [1].

The textile sector demands a high amount of water in its production chain, producing a high quantity of residual water. The primary and secondary parts of textile processing require more water due to dyeing of a given substrate [2]. The cotton fiber stands out as the most consumed by the clothing sector, and more than half of its production is dyed with reactive coloring agents. The molecules of such dyeing are reacting to the fibers in alkaline $\mathrm{pH}$, through Hydrogen Bonds, Van der Waals Force and, also, through Covalent Bonds [3]. However, as well as the reaction between dyestuff and fiber, it also generates the reaction between dyestuff and the water used in the bathing, known as hydrolyzed dyestuff.

The dyestuffs hold lengths of electromagnetic waves that fluctuate from 400 to $720 \mathrm{~nm}$, a range known as visible spectrum. They can be rated by its chemical structure, its application, according to the fiber used in the dyeing, or by its commercial trademark [4].

The commercial name of a dyestuff is contained in the base of the International Color Index (single and global classification system of colors) and can be identified through the CAS number with respect to the registration of a particular chemical compound available in the Chemical Abstracts Service database. The dyestuff used in this study was the C.I. Reactive Blue 21 (RB 21): molecular mass equal to $1079.53 \mathrm{~g} \mathrm{~mol}^{-1}, \mathrm{n}^{\mathrm{o}} \mathrm{CAS} 12236-86^{-1}$, Homofunctional, reactive group Vinylsulphone and chromophore group Phthalocyanine. It is employed in colors with shades of green water, dark green and turquoise. Its structure is shown in Figure 1.

Figure 1: Molecular Structure of the RB 21 dyestuff 


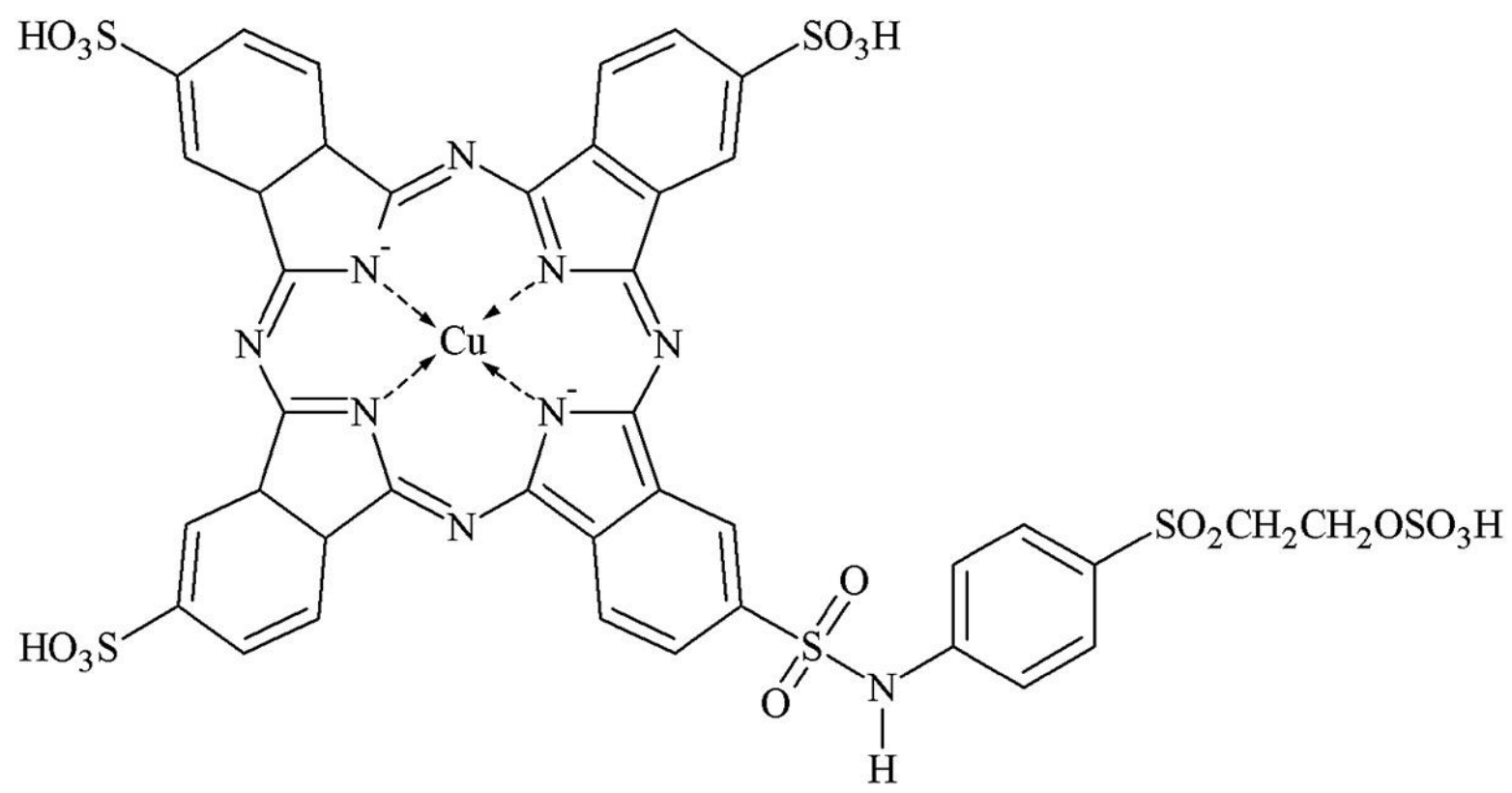

Source: Rosa et al. 2019

The textile effluents contain high amount of dyestuffs, bleaching agents, salts, acids, alkalis, metals, suspended solids; some of these with low biodegradability and high solubility, for example surfactants, which makes them difficult to remove by conventional effluent treatment. These compounds can interact and change the major components of the cell membrane, proteins and lipids of organisms. In aquatic organisms, alterations in growth, reproduction and motility were observed and correlated to textile pollution $[5,6]$.

The variation in the color of the derived effluent is substantial, generating absorptiometric units in the range from $420 \mathrm{~nm}$ to $600 \mathrm{~nm}[7,8]$. This is due to the strong coloring and high solubilization of the dyestuffs, even with low concentrations, which contribute to reduce the penetration of light in aquatic systems. Therefore, it is necessary to review, in addition to the absorptiometric index, other parameters such as the concentration of dissolved oxygen in the water and the possible induction of toxicity to the aquatic organism.

According to M.A. Rauf and S. Salman Ashraf [9], the Advanced Oxidation Processes (AOP) are a set of techniques that normally uses a strong oxidant that makes a sequence of reactions, splitting the macromolecule into smaller and less harmful substances. Moreover, they argue that the degradation of the dyestuffs starts, exclusively, by the attack of $\mathrm{OH} \bullet$ in places rich in electrons 
from the dyestuff molecules. The radical $\mathrm{OH} \bullet$ formed is the main reactive kind that degrades the dyestuff, destroying or changing the structure of its chromophore group [10].

The ionizing radiation, by electron beams, appeared as an option to the advanced oxidation process for the effluent treatment through important reactive kinds for the oxidation of organic contaminants [11].

The identification of possible biological damage to the environment can be made through standard toxicity tests, in which sensitive organisms are submitted to a certain toxic compound with the aim of establishing level of effects, whether lethal or sub-lethal. The acute toxicity tests, for example, allow us, in a short period of time, to evaluate part of life cycle of the organism; immobility or mortality, influence on biochemical reactions, among other effects [12].

The objective of this study was to evaluate electron beam irradiation technology, applied in samples of RB 21 and surfactant non-ionic in order to analyze the toxicity, color reduction, exhaustion degree, and the $\mathrm{pH}$.

\section{MATERIALS AND METHODS}

The methodology of this work consisted in analyzing RB 21 dyestuff submitted to Electron Beam Treatment, in order to evaluate the toxicity, and other parameters, such as Absorptiometric Decay, the Dyestuff Exhaustion Level and the pH obtained after treatment. Acute toxicity of nonionic surfactant, before and after the irradiation, was evaluated.

\subsection{Preparation of the samples}

The reactive dyestuff and surfactant aqueous solution were prepared at LEBA (Environmental and Biological Assays Laboratory) as described below.

- Dyestuff RB 21: the concentration $0.61 \mathrm{~g} \mathrm{~L}^{-1}$ was used on the basis of the study developed by Rosa et al. [13], assessing the exhaustion degree to RB 21 dyestuff, with standard concentration of $1.5 \mathrm{~g} \mathrm{~L}^{-1}$ in the manufacturer dyestuff. This study determined that only $59.29 \%$ of the dyestuff migrated to the fiber that is $40.71 \%$ of the dyestuff remained in the dyeing bath. Therefore, it was interesting to analyze the fact that, stemming from the initial concentration of dyestuff, $0.61 \mathrm{~g} \mathrm{~L}^{-1}$ stayed in the effluent. 
- Surfactant (non-ionic): it was analyzed at the concentration of $1 \mathrm{~g} \mathrm{~L}^{-1}$, the same used for cotton fiber processing.

\subsection{Irradiation of the samples}

The EBI of samples was carried out at an Industrial Electron Beam Accelerator, Dynamitron, at Centro de Tecnologia das Radiações/ IPEN - CNEN/ SP. The irradiations were performed at a batch processing and samples contained in glass Pyrex ${ }^{\circledR}$ and covered with plastic film. The speed of the conveyer belt was $6.72 \mathrm{~m} \mathrm{~min}^{-1}$, variable current and $1.4 \mathrm{MeV}$ fixed energy.

The doses applied during this study were: $2.5 \mathrm{kGy}$ and $5 \mathrm{kGy}$ for dyestuff solutions and 2.5 kGy for surfactant samples.

\subsection{Ecotoxicological Assays}

The acute toxicity was evaluated with microcrustacean Daphnia similis, in accordance with the NBR 12713/ 2016 [14]. The criteria applied for choosing this organism was its high sensibility to chemical agents, and its bioavailability, and relatively simple maintenance in laboratory standard conditions. The daphnids used for acute toxicity measurements were removed from the LEBA culture.

Were carried preliminary and definitive assays based on the exposition of young organisms (between 6 to 24 hours - young), for a period of 48 hours, for determining the concentration of the toxic agent that caused immobility or mortality to $50 \%$ of exposed organisms (EC 50).

The EC 50 values were based on immobility raw data and Trimmed Spearkman - Karber method analysis [15]. The validation of these assays was based on a negative control. Furthermore, according to the recommendations of ABNT standard procedure, the sensitivity of organisms for Potassium Chloride was measured as a reference substance.

As EC 50 values are an inversely proportional parameter, it is common to use the Toxic Unit calculation. The Toxic Unit (TU) express a direct value, namely, the higher its numeric value, the higher will be the toxicity of the analyzed sample. It can be obtained through the following sequence [16].

$$
T U=\frac{100}{E C 50}
$$




\subsection{Absorptiometric Decay}

The absorptiometric decay (AD) that involves the level of color reduction, was determined by using acrylic buckets with thickness of $1.0 \mathrm{~cm}$ through the visible spectrophotometer in the SENAI/SP facilities. A length reading ranging from $400 \mathrm{~nm}$ to $700 \mathrm{~nm}$ was made with the raw and irradiated samples. The calculation of AD was obtained by the equation:

$$
A_{\mathrm{D}}=\left[\frac{A_{0-} A_{f}}{A_{0}}\right] \times 100
$$

$\mathrm{A}_{0}=$ Initial absorbance;

$\mathrm{A}_{\mathrm{f}}=$ Final absorbance.

\subsection{Exhaustion Degree}

The exhaustion degree consists in quantifying the concentration of the dyestuff existing in the solution. The calculation has its base through the preparation of a solution with concentration $0.61 \mathrm{~g}$ $\mathrm{L}^{-1}$ of RB 21 and, in the sequence, this solution was diluted in 10 samples with a reduction of $10 \%$ each until the final concentration.

The absorbance of all samples was evaluated through the visible spectrophotometer, under an illuminant $\mathrm{D} 65,10^{\circ}$ and, with the values obtained and its concentrations, a theoretical adjustment curve was drawn, in addition to an equation base to calculate the dyestuff concentration in the sample after the irradiation.

\section{RESULTS AND DISCUSSION}

The toxicity results of Daphnia similis exposed to samples of RB 21 dyestuff and non-ionic surfactant were organized in Table 1. Similar data was obtained to all samples of reactive RB 21 dyestuff before and after irradiation with $2.5 \mathrm{kGy}$ and $5 \mathrm{kGy}$. On the other hand, the surfactant was very toxic for $D$. similis and much more toxic if compared to RB 21 dyestuff. After irradiation with $2.5 \mathrm{kGy}$ the toxic units were reduced (Table 1).

In addition to the toxicity analysis, we evaluated the color of the samples in relation to the absorbed dose. The Figure 2 represents the absorbance reading of the raw and irradiated samples of 
the RB 21 dyestuff by visible spectrophotometry in $620 \mathrm{~nm}$, in which it is possible to observe a significant decrease in the absorbance of the irradiated sample. It was possible to verify a degree of discoloration of $19.55 \%$ in the sample irradiated with $2.5 \mathrm{kGy}$ and $24.60 \%$ in the sample irradiated with $5 \mathrm{kGy}$.

Table 1: Values of EC 50 and TU in raw and irradiated samples.

\begin{tabular}{ccc}
\hline Sample & EC 50 $_{\mathbf{4 8 h}}(\boldsymbol{\%})$ & TU \\
\hline RB21 $-0.61 \mathrm{~g} \mathrm{~L}^{-1}(0 \mathrm{kGy})$ & $61.12(53.17-70.26)$ & 1.64 \\
$\mathrm{RB} 21-0.61 \mathrm{~g} \mathrm{~L}^{-1}(2.5 \mathrm{kGy})$ & $58.26(55.87-60.75)$ & 1.72 \\
$\mathrm{RB} 21-0.61 \mathrm{~g} \mathrm{~L}^{-1}(5 \mathrm{kGy})$ & $63.59(61.30-65.96)$ & 1.57 \\
Surfactant $-1.0 \mathrm{~g} \mathrm{~L}^{-1}(0 \mathrm{kGy})$ & 0.42 & 238.09 \\
Surfactant $-1.0 \mathrm{~g} \mathrm{~L}^{-1}(2.5 \mathrm{kGy})$ & 0.46 & 217.39 \\
\hline
\end{tabular}

He et al. [17] applied EBI as support in the biodegradability of textiles effluents. The results showed that irradiation after biological process can increase the biodegradability up to $224 \%$. Borrely et al. [18] investigated three textile samples regarding its color and toxicity. After the EBI, $80 \%$ toxicity removals were obtained for $V$. fischeri, D. similis and B. plicatilis.

Silva et al. [19] evaluated the discoloration of the solution of the reactive dyestuff RB 21 and its oxidation products, based on the enzymatic treatment with turnip peroxidase combined with the addition of $\mathrm{H}_{2} \mathrm{O}_{2}$ and obtained a discoloration of $57.7 \%$ (addition of $20.3 \mathrm{U} \mathrm{mL}^{-1}$ of enzyme) and an increase of more than $50 \%$ in toxicity at a concentration of $100 \%$.

The adsorption process using banana peel flour was used by Franqueto [20] to discoloration the Reactive Blue QR - 19 dyestuff. The maximum adsorption efficiency occurred after factorial planning with $38 \%$ discoloration, to 0.5 grams of adsorbent.

As for ionizing radiation applied in dyestuff solutions, Wang et al. [21] showed that the electron beam irradiation allowed $51 \%$ discoloration of Reactive Blue XBR dyestuff (addition of $\mathrm{H}_{2} \mathrm{O}_{2}$ ) at a dose of $10 \mathrm{kGy}$. For the solution with the Reactive Blue 2 dyestuff in a concentration of $0.02 \%$, Vahdat et al. [22] achieved 38\% color removal at a dose of $3 \mathrm{kGy}$.

In Table 2, these studies were organized addressing the different methods for discoloration and / or possible harmful effects from reactive dyestuffs in aqueous solution. 
Table 2: Studies with reactive blue dyestuffs and different treatment methods

\begin{tabular}{l|l|l|l}
\hline \multicolumn{1}{c|}{ Dyestuff } & \multicolumn{1}{c|}{$\begin{array}{c}\text { Treatment } \\
\text { Method }\end{array}$} & \multicolumn{1}{c}{$\begin{array}{c}\text { Toxicity and / or } \\
\text { discoloration }\end{array}$} & \multicolumn{1}{c}{ Reference } \\
\hline $\begin{array}{l}\text { Reactive Blue } \\
21\end{array}$ & $\begin{array}{l}\text { Turnip Peroxidase } \\
\text { Enzyme }\end{array}$ & $\begin{array}{l}\text { Toxicity }\left(\mathrm{LC}_{50}\right) \\
\text { Raw dyestuff: }- \\
\text { Treated dyestuff: } 74.60 \% \\
\text { Discoloration: } 57.7 \%\end{array}$ & SILVA et al., 2011 \\
\hline $\begin{array}{l}\text { Reactive Blue } \\
\text { QR - 19 }\end{array}$ & $\begin{array}{l}\text { Adsorption with } \\
\text { the use of banana } \\
\text { peel }\end{array}$ & $\begin{array}{l}\text { Toxicity: }- \\
\text { Discoloration: } 38 \%\end{array}$ & FRANQUETO, 2017 \\
\hline $\begin{array}{l}\text { Reactive Blue } \\
\text { XBR }\end{array}$ & $\begin{array}{l}\text { Electron Beam } \\
\text { Irradiation }\end{array}$ & $\begin{array}{l}\text { Toxicity: }- \\
\text { Discoloration: } 51 \%\end{array}$ & WANG et al., 2006 \\
\hline Reactive Blue 2 & $\begin{array}{l}\text { Electron Beam } \\
\text { Irradiation }\end{array}$ & $\begin{array}{l}\text { Toxicity: }- \\
\text { Discoloration: } 43 \%\end{array}$ & VAHDAT et al., 2012 \\
\hline
\end{tabular}

As observed, there are several treatment processes applied to the degradation of textile dyes, but it is necessary to take into account the possible unwanted formation of secondary products from the treatment, which will also need to be treated.

The dyestuffs studied have different chromophore groups, with different molecular structures, which reflects not only in obtaining different shades of blue, but also in the stability of the dyestuff molecule bonds and, consequently, in the degradation capacity.

The difficulty of removing or the increasing toxicity in solutions containing the RB 21 dyestuff may be associated with the phthalocyanine type chromophore group, whose molecular structure, in the form of a chelate, is composed of a copper atom. After the breakdown of the chromophore group, the dyestuff molecule, previously complexed, starts to release copper ions favoring the increase of toxicity in solution or generating by-products more toxic than the pretreatment solution [19].

Regarding the $\mathrm{pH}$ values from the irradiated samples, it is shown a decrease: for RB 21 dyestuff initial $\mathrm{pH}$ of 5.90 decreases to $4.92(2.5 \mathrm{kGy})$, and then to 4.76 (5 kGy). This acidity increases due to the formation of organic acids coming from the organic compounds degradation [23]. In this study, high toxicity to D. similis, EC $50\left(\mathrm{mg} \mathrm{L}^{-1}\right)$ was determined for surfactants. From other authors, Romanelli et al. [24] indicates important toxicity values for sodium dodecyl sulfate EC 50\% 1.92 to V. fischeri and EC 50\% 11.81 to D. similis. For Linear alkylbenzene sodium, 13.49 
(V. fischeri) and 4.56 (D. similis) were reported. To the same surfactant, Hodges et al. [25] found values from $0.67 \%$.

Figure 2: Reading of concentration sample $0.61 \mathrm{~g} \mathrm{~L}^{-1}$ absorbance

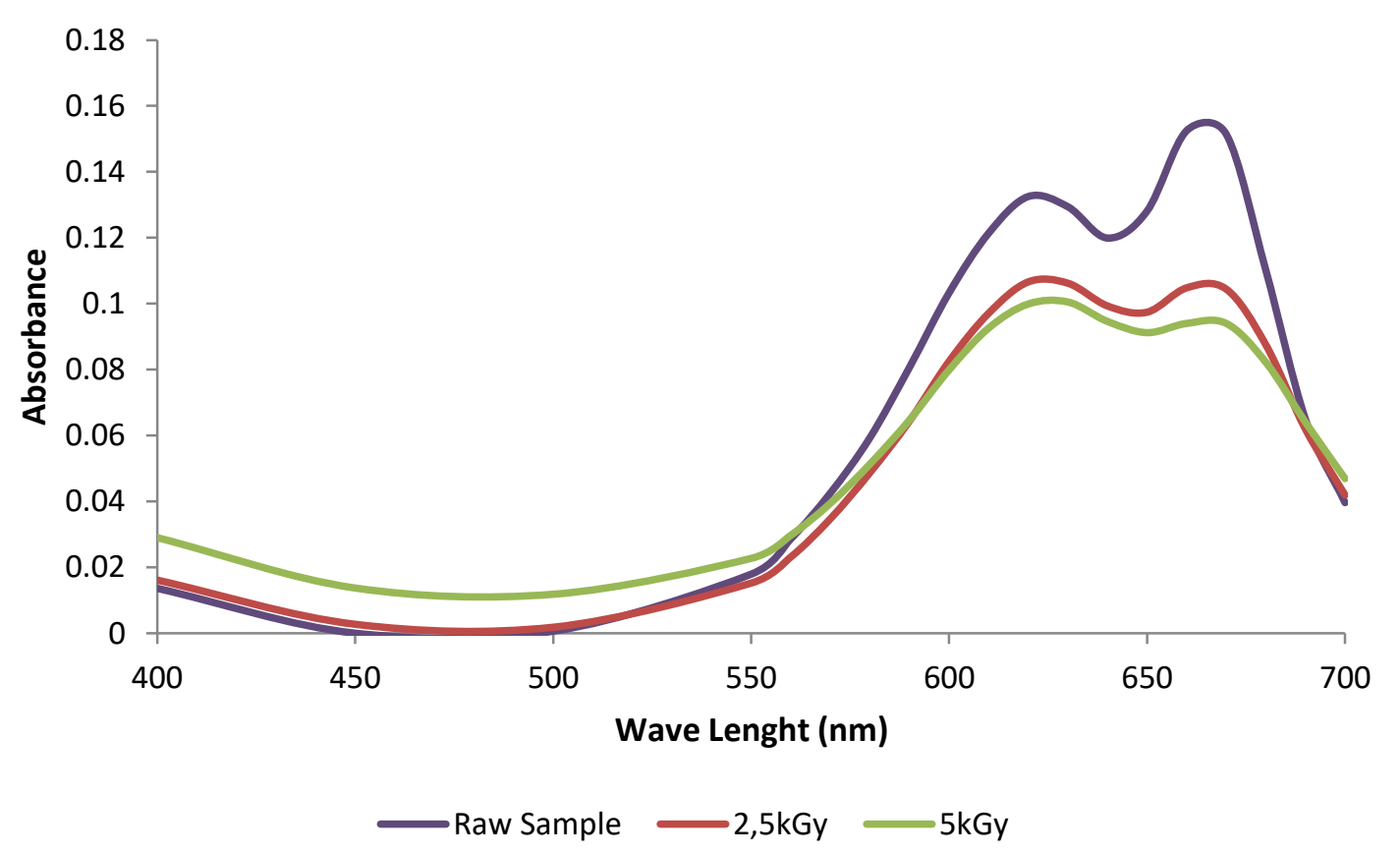

Source: Author

It is known that many materials have their coloration altered when exposed to ionizing radiation. The samples of the figure bellow were diluted for better visualization, which allows us to verify that the effect of ionizing radiation on the dyestuff solution, in addition to color reduction.

Figure 3: Raw and irradiated samples 


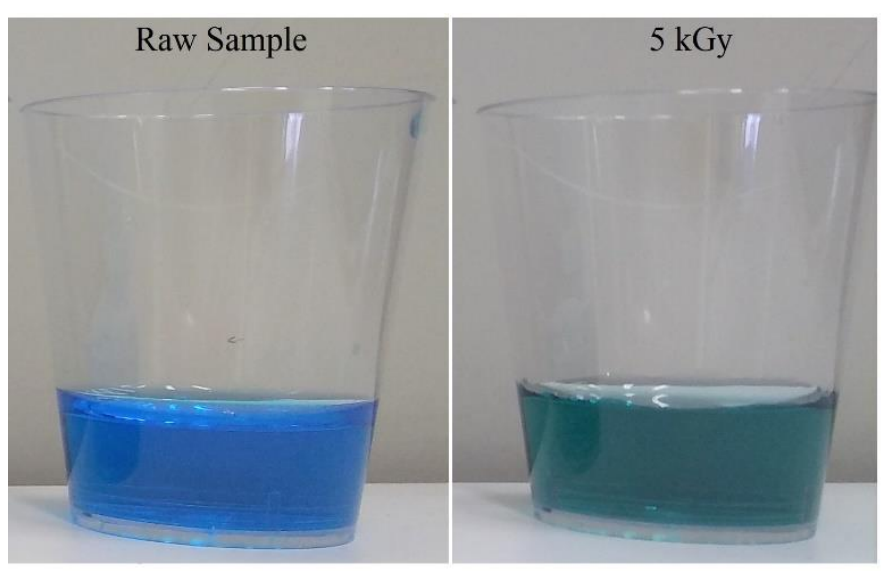

Source: Author

The interaction between the radiation and the solution led to the modification of the optical properties of the dyestuff structure [26]. Treatments by adsorption have been used for the dyestuff removal, like Vanaamudan, Chavada e Padmaja [27], who studied the adsorption in hydrotalcite, obtaining the values of $226 \mathrm{mg} \mathrm{g}^{-1}$, that are ideal to the RB 21 absorption in $\mathrm{pH}$ 2.0. Sohrabi et al. [28] obtained $95 \%$ of RB 21 removal in aqueous solution through the adsorption of iron compounds.

Correlating the absorbance data with the dilution concentrations, a theoretical calibration curve allowed us to calculate the concentration of dyestuff present in the sample after irradiation. For this work, with the base of the calibration curve, the following equation was obtained:

$$
R B 21_{n}=\frac{A b s_{n}+0,2501}{6,6333}
$$

Based on equation 3 and in the initial concentration of dyestuff of $0.61 \mathrm{~g} \mathrm{~L}^{-1}$, the following RB 21 concentration values were obtained after the irradiation process: $0.0538 \mathrm{~g} \mathrm{~L}^{-1}$ (2.5 $\mathrm{kGy}$ ) and $0.0528 \mathrm{~g} \mathrm{~L}^{-1}(5 \mathrm{kGy})$. Therefore, the results demonstrated the reduction to a final concentration of Reactive Blue 21.

\section{CONCLUSIONS}


The electron beam irradiation was effective for the discoloration of aqueous solutions of the RB 21 dyestuff, with $24.60 \%$. Regarding the toxicity, the surfactant solution showed a low value of EC 50 and can be rated as highly toxic product. In this regard, no improvement was obtained by irradiation. If comparing acute toxic effects, the surfactant was much more toxic than the RB 21 dyestuff. Irradiation-based technology may be feasible once several organics can be reduced at the same time and with relatively low dose.

\section{ACKNOWLEDGMENTS}

We would like to thank Faculdade de Tecnologia SENAI Antoine Skaf and Instituto de Pesquisas Energéticas e Nucleares. Both provided necessary resources to the development of this work. Our thanks also to the Conselho Nacional de Desenvolvimento Científico e Tecnológico $(\mathrm{CNPq})$, by the financial assistance granted.

\section{REFERENCES}

[1] LEITE, A.S.; BARCO, L.; TRINDADE, N.B.; ARAÚJO, M.C.; BEZERRA, R.N., ROSA, J.M.; COSTA, J.M. Custos ecológicos e sustentabilidade em recursos hídricos na indústria têxtil. Revista de Ciências Gerenciais, v. 17, p.103-111, 2013.

[2] ROSA, J.M.; GARCIA, V.S.G.; BOIANI, N.F.; MELO, C.G.; PEREIRA, M.C.C.; BORRELY, S.I. Toxicity and environmental impacts approached in the dyeing of polyamide, polyester and cotton knits. Journal of Environmental Chemical Engineering, v. 7, p. 102973-7, 2019.

[3] GUARATINI, C.C.I; ZANONI, M.V. Corantes têxteis. Revista Química Nova, v. 23, p. 72-78, 2000).

[4] GOMES MELO, C.; SOUZA, R.C.; MARCOS ROSA, J. Colorimetria: O banco de dados em tinturarias. Química Têxtil, v. 95, p. 36-47, 2009.

[5] FERNÁNDEZ SERRANO, M.; JURADO, E.; FERNÁNDEZ ARTEAGA, A.; RÍOS, F; LECHUGA, M. Ecotoxicological Assessment of Mixtures of Ether Carboxylic Derivative and 
Amine Oxide Based Non-ionic Surfactants on the Aquatic Environment. Journal of Surfactants and Detergents, v. 17, p. 1161-1168 2014.

[6] REBELlO, S.; ASOK. A. J.; MUNDAYOOR, S.; JISHA, M. S. Surfactants: toxicity, remediation and green surfactants. Environ Chem Lett, v. 12, p. 275-287, 2014.

[7] LYKIDOU, S.; KARANIKAS, E.; NIKOLAIDIS, N; TSATSARONI, E. Azo reactive dyes: ultrafiltration and application to cotton by exhaustion and digital ink-jet printing. Textile Research Journal, v. 86, p. 823-836, 2015.

[8] CHEN, L.; WANG, B.; RUAN, X.; CHEN, J.; YANG, Y. Hydrolysis-free and fully recyclable reactive dyeing of cotton in green, non-nucleophilic solvents for a sustainable textile industry. Journal of Cleaner Production, v. 107, p. 550-556, 2015.

[9] RAUF, M.A.; ASHRAF, S.S. Radiation induced degradation of dyes - An overview. Journal of Hazardous Materials, v. 166, p. 6-16, 2009.

[10] ABDOU, L.A.W.; HAKEIM O.A.; MAHMOUD M.S.; EL-NAGGAR A.M. Comparative study between the efficiency of electron beam and gamma irradiation for treatment of dye solutions, Chemical Engineering Journal, v. 168, p.752-758, 2011.

[11] MADUREIRA, J.; MELO, R.; PIMENTA, A.I.; VERDE, S.C.; BORRELY, S.I. Evaluation of e-beam irradiation effects on the toxicity of slaughterhouse wastewaters, Environmental Technology, v. 39, p. 873-977, 2017.

[12] BORRELY, S.I. Redução da toxicidade aguda de efluentes industriais e domésticos tratados por irradiação com feixes de elétrons, avaliada com as espécies Vibrio fisheri, Daphnia similis, Poecilia reticulata. 2001. Tese (Doutorado em Tecnologia Nuclear) Instituto de Pesquisas Energéticas e Nucleares, São Paulo, 2001.

[13] ROSA, J.M.; MELO, C.G.; PEREIRA, M.C.C.; Borrely, S.I. Reactive Blue 21 exhaustion degree investigated using the Surface Response Methodology as an auxiliary tool in cotton dyeing. Journal of Natural Fibers, v. 16, p.1-11, 2019.

[14] ASSOCIAÇÃO BRASILEIRA DE NORMAS TÉCNICAS. ABNT NBR 12713: Ecotoxicologia aquática - Toxicidade Aguda- Método de ensaio com Daphnia spp (Crustacea, Cladocera). Rio de Janeiro: ABNT, 2016. 
[15] HAMILTON, M.A.; RUSSO, R.C.; THURSTON, R.V. Trimmed Spearman Karber Method for estimating median lethal concentrations on toxicity bioassays. Environmental Science \& Technology, v. 11, p. 714-719, 1977.

[16] ZAGATTO, E. B.; BERTOLETTI, E. Ecotoxicologia aquática - princípios e aplicações, $2^{a}$ ed. São Paulo: Rima, 2008.

[17] HE, S.; SUN, W.; WANG, J.; CHEN, L.; ZHANG, Y.; YU, J. Enhancement of biodegradability of real textile and dyeing wastewater by electron beam irradiation. Radiation Physics and Chemistry, v. 124, p. 203-207, 2016.

[18] BORRELY, S. I.; MORAIS, A. V.; ROSA, J. M.; BADARÓ-PEDROSO, C.; PEREIRA, M. C.; HIGA, M. C. Decoloration and detoxification of effluents by ionizing Radiation. Radiation Physics and Chemistry, v. 124, p. 198-202, 2016.

[19] SIlVA, M. C.; CORRÊA, A. D.; AMORIM, M. T. S. P.; PARPOT, P.; TORRES, J. A.; CHAGAS, P. M. B. Decolorization of the phthalocyanine dye reactive blue 21 by turnip peroxidase and assessment of its oxidation products. Journal of Molecular Catalysis B: Enzymatic, v. 77, p. 9-14, 2012.

[20] FRANQUETO, R. Descoloração dos corantes azul QR-19 e magenta por processo de adsorção com uso de farinha de casca de banana. Revista Gestão \& Sustentabilidade Ambiental, v. 5, p. 247-264, 2017.

[21] WANG, M.; YANG, R.; WANG, W.; SHEN, Z.; BIAN, S.; ZHU, Z. Radiation-induced decomposition and decoloration of reactive dyes in the presence of $\mathrm{H} 2 \mathrm{O} 2$. Radiation Physics and Chemistry, v. 75, p. 286-291, 2006.

[22] VAHDAT, A.; BAHRAMI, S. H.; ARAMI, M.; BAHJAT, A.; TABAKH, F.; KHAIRKHAH, M. Decoloration and mineralization of reactive dyes using electron beam irradiation, Part I: Effect of the dye structure, concentration and absorbed dose (single, binary and ternary systems). Radiation Physics and Chemistry, v. 81, p. 851-856, 2012.

[23] SUZUKI, N.; MIYATA, T.; SAKUMOTO, A.; HASHIMOTO, S.; KAWAKAMI, W. The degradation of an azo dye in aqueous solutions by high-intensity electron beam irradiation. The International Journal of Applied Radiation and Isotopes, v. 29, p. 103-108, 1978. 
[24] ROMANElli, M. F.; MORAES, M. C. F.; VILlAVICENCIO, A. L. C. H.; BORRELY, S. I. Evaluation of toxicity reduction of sodium dodecyl sulfate submitted to electron beam radiation. Radiat Phys Chem, v. 71, p. 411-413, 2004.

[25] HODGES, G.; ROBERTS, D.W.; MARShALL, S. J.; DEARDEN, J. C. The aquatic toxicity of anionic surfactants to Daphnia magna - A comparative QSAR study of linear alkylbenzene sulphonates and ester sulphonates. Chemosphere, v. 63, p. 1443-1450, 2006.

[26] MÓDIS, L. Organization of the Extracellular Matrix: A Polarization Microscopic Approach, $1^{\text {st }}$ ed. New York: CRC Press, 2018.

[27] VANAAMUDAN, A.; CHAVADA, B.; PADMAJA, P. Adsorption of reactive blue 21 and reactive red 141 from aqueous solutions onto hydrotalcite. Journal of Environmental Chemical Engineering, v. 4, p. 2617-2627, 2016.

[28] SOHRABI, M. R.; MOGHRI, M.; MASOUMI, H. R. F.; AMIRI, S.; MOOSAVI, N. Optimization of Reactive Blue 21 removal by Nanoscale Zero-Valent Iron using response surface methodology. Arabian Journal of Chemistry, v. 9, p. 518-525, 2016. 